\title{
GEOGRAPHICAL LOCATION AND SOLAR SALT PRODUCTION
}

\author{
localização geográfica e produção de sal \\ Diógenes Félix da Silva Costa * \\ Renato de Medeiros Rocha ** \\ Gesinaldo Ataíde Candido *** \\ Amadeu Mortágua Velho da Maia Soares ****
}

\begin{abstract}
Along the Brazilian shoreline, on the northern coast of Rio Grande do Norte State Brazil) are located the largest solar saltworks of the country. The present research aims to evaluate the sustainability of the consumption of estuarine water and the area required for salt production in Brazilian solar saltworks situated along the estuary of the River Apodi-Mossoró (Rio Grande do Norte State). The analysis of the total area of production values, water volume estuary used and annual salt production was carried out, relating to the area required for this production in a solar saltwork located upstream ( lower estuary) and another downstream (high estuary) in this estuary. That due to high salinity values of estuarine water upstream, the downstream saltworks require a production area three times larger than those located upstream, which obtain a production only twice superior. It was verified that the saltworks located downstream utilize the largest area and require more water volume for salt production.
\end{abstract}

Key words: Wetlands; Salt production; Management; Brazil.

\section{Resumo}

Ao longo do litoral do Brasil, apenas no trecho setentrional do estado do Rio Grande do Norte estão situadas as maiores empresas salineiras do país. A pesquisa em questão teve como objetivo central avaliar a sustentabilidade do consumo de água e uso do solo para a produção de sal marinho nas salinas situadas ao longo do estuário hipersalino do Rio Apodi-Mossoró (RN). Foi realizada a análise dos valores de área total de produção, volume de água do estuário utilizado e produção anual de sal, relacionando-se a área necessária para essa produção em uma salina situada a montante (baixo estuário) e outra a jusante (alto estuário) desse estuário. Verificou-se que as salinas do baixo estuário utilizam uma área de produção três vezes superior à área utilizada pelas salinas do alto estuário, conseguindo obter uma produção apenas duas vezes superior. Por apresentar uma área maior, as salinas do baixo estuário apresentam uma demanda superior de volume de água, necessitando da alocação de extensas áreas para armazenamento e produção de sal.

Palavras-chave: Áreas úmidas; Litoral semiárido; Recursos hídricos; Produção de Sal.

\section{Résumé}

Les plus grandes entreprises salinières du Brésil se trouvent le long du littoral nord de l'état du Rio Grande du Nord. L'objectif principal de la recherche en question était de chercher à évaluer la durabilité de consommation de l'eau et l'utilisation des sols pour la production de sel marin dans les salines situé sur le long de l'estuaire hypersalin du fleuve Apodi-Mossoro (RN). Nous avons effectué une analyse des valeurs surface totale de production, volume d'eau utilisé dans l'estuaire et production annuelle du sel en se référant à la surface nécessaire pour cette production dans une saline en amont (estuaire haut) et une autre en aval (estuaire basse). Il a été constaté que les salines de l'estuaire aval utilisent une zone de production trois fois plus grande que celle utilisée par les salines de l'estuaire amont obtenant une production trois fois supérieur à la zone utilisée par les salines de l'estuaire amont, permettant une production à peine deux fois plus grande. Par sa plus grande superficie, les salines de l'estuaire aval représentent une demande supérieure au volume d'eau, nécessitant l'allocation de zones d'extensions pour le stockage et la production de sel.

Mots clés: Zones Humides; Côte semi-aride; Ressourses hydriques; Production de sel.

(*) Prof. Dr. do Programa de Pós-Graduação em Geografia da Universidade Federal do Rio Grande do Norte - Campus de Caicó. Rua Joaquim Gregório, s/n., CEP: 59300-000, Caicó (RN), Brasil. Tel (+55 84) 3421-4870 - diogenesgeo@gmail.com

(**) Prof. Dr. do Departamento de Geografia, Universidade Federal do Rio Grande do Norte - Campus de Caicó. Rua Joaquim Gregório, s/n., CEP: 59300-000, Caicó (RN), Brasil. Tel (+55 84) 3421-4870 - renatocaico@yahoo.com.br

(***) Prof. Dr. do Programa de Pós-Graduação em Recursos Naturais, Departamento de Administração, Centro de Humanidades, Universidade Federal de Campina Grande - Rua Aprígio Veloso, 882, Bairro Universitário, CEP: 58.429-140, Campina Grande (PB), Brasil. Tel.: (+5583) 2101-1200 - E-mail: gacandido@uol.com.br

(****) Prof. Dr. do Departamento de Biologia/Centro de Estudos do Ambiente e do Mar, Universidade de Aveiro - Campus Universitário de Santiago, CEP: 3810-193, Aveiro, Portugal. Tel.: (+35123) 234370792 - E-mail: asoares@ua.pt 


\section{INTRODUCTION}

The largest saltworks of Brazil are located along the Brazilian shoreline, on the northern coast of Rio Grande do Norte State (Brazil), mainly on the margins of the estuaries (DE MEDEIROS ROCHA et al., 2009; COSTA, 2010). The saltworks studied in this stretch of Brazilian coast account for $97 \%$ of the national sea salt production and exportation, directly influencing local and regional economies through job creation and payment of taxes (DE MEDEIROS ROCHA et al., 2009).

The location of saltworks along the estuaries of major rivers on this coast is due to a set of environmental factors such as a semiarid climate with high temperatures $\left(>28^{\circ} \mathrm{C}\right)$, low rainfall $(<800$ $\mathrm{mm}$.year-1) and high evaporation rates along with the availability of water in the estuary, besides the existence of extensive plains. The combination of these factors makes the estuary hypersaline, during much of the year (dry season), reaching salinity between 45 and 90 ppm (RAMOS e SILVA, 2004; SILVA et al., 2009). Thus the water body operates as a natural evaporator of waters, benefiting the saltworks that already capture water with a high content of salt.

Considering that environmental conditions directly influence the production process of salting activity (DE MEDEIROS ROCHA e CAMARA, 1993; DAVIS, 2000; SOUTO et al., 2000a,b; MOOSVI, 2006; KOROVESSIS E LEKKAS, 2009), there is a lack of environmental indicators that allow identifying which environmental characteristics of a given area may influence the sustainability of sea salt production in solar saltworks (DAVIS, 2009). In this way, the present study aimed to evaluate the sustainability of estuarine water consumption and land use for sea salt production in saltworks located along the estuary of the River Apodi-Mossoró, on the northern coast of Rio Grande do Norte State (Brazil).

In this zone, saltworks are one of the most present units in the landscape, where their functioning is strictly related with the spatial variable (COSTA, 2010). These water bodies still work as complex artificial ecosystems, mainly regarding the structure, functioning and evolution (PEDRÓS-ALIÓ et al., 2000; OREN, 2009; LÓPEZ et al., 2010; VIEIRA e BIO, 2011). Thus, the analysis of the area required for production and its relationship with environmental aspects involved in this process became essential in the perspective of integrative functionality between the characteristics of the environmental system of the saltworks and of the economic system in which is inserted. It also helps understanding the dynamics of land use and occupation along the estuary and the implications of these dynamics on the environmental sustainability of the region.

Therefore, the saltworks emerge as a dominant component in this region, where the area dedicated to salt production and the volume of consumed estuarine water are two basic components of this production system. We show that combining these two elements gives keys for explaining the presence of solar saltworks along the estuary of the Apodi-Mossoró River (Brazil). In this way, the two indicators selected to evaluate the sustainability of sea salt production confirm the relevance of these physical and environmental parameters for understanding the process of land use and occupation.

\section{MATERIAL AND METHODS}

\section{Study areas}

The data collection was based on two saltworks, the first being the Salina Miramar (NORSAL - Norte Salineira S.A. Trade and Industry), situated near the estuary mouth (4'56'37' S / $37^{\circ} 08^{\prime}$ 19 "W). This company was chosen as a representative area of salt production near the river mouth, whose environment of water abstraction differs from that observed upstream from the estuary. The second was the São Camilo (Salineira São Camilo LTDA), located in the upstream stretch of the estuary (Figure 1). 

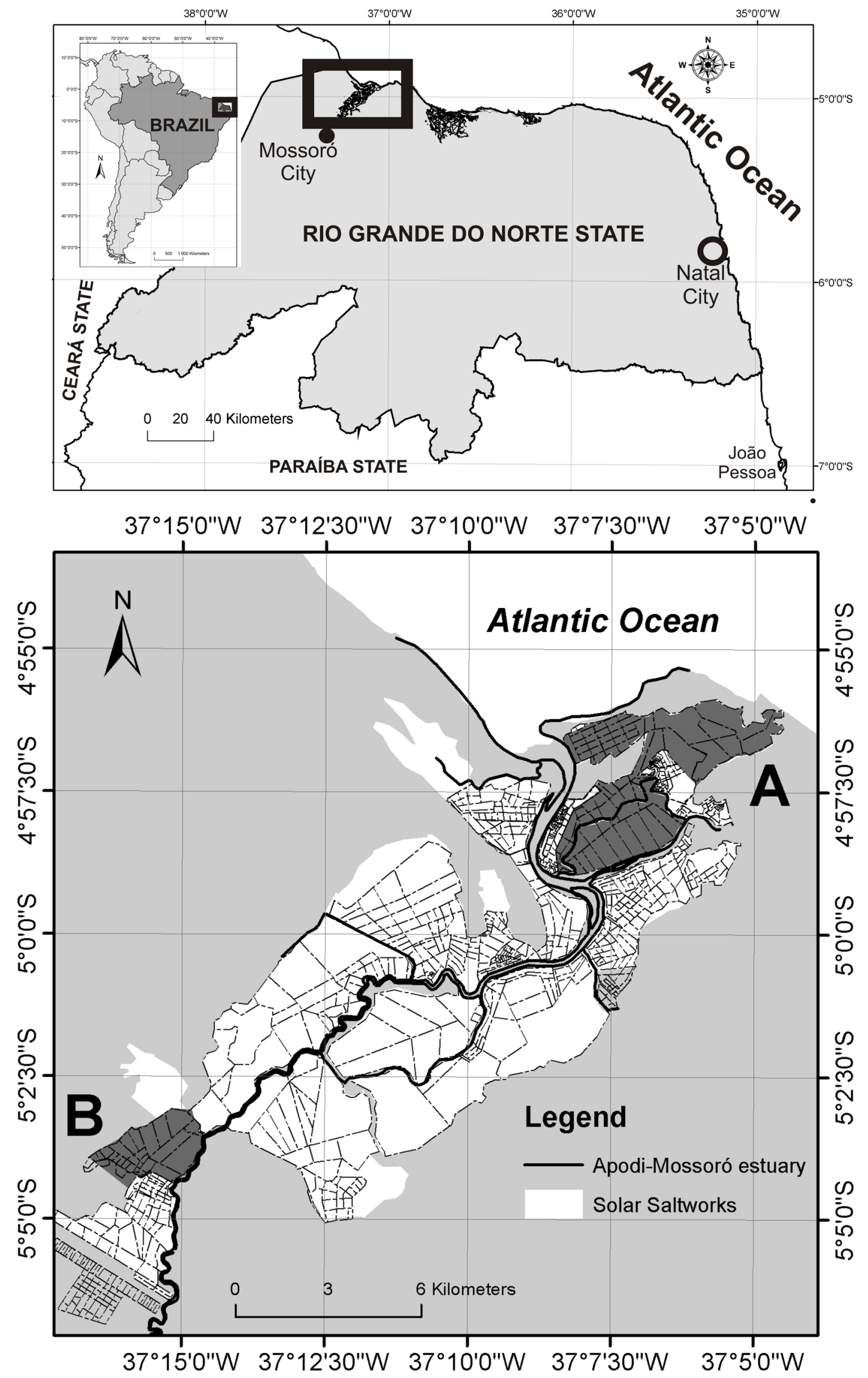

Figure 1 - Location of the study area 


\section{Methods}

To analyze the sustainability of sea salt production, we listed two criteria to guide the analysis: 1) consumption of raw material (estuarine water) and 2) area used for the production. These two criteria were associated to the following data: production area (hectare - ha), total annual production (ton.), salinity in the local of water abstraction ( $\mathrm{ppm}$ ), number of water pumps per saltwork, and pumping rate (m3.hour-1).

After selecting sampling areas, we processed our data through use of the Geographic Information System set up by De Medeiros Rocha (2005) for the Environmental Defense Institute of Rio Grande do Norte State. This database, besides the abovementioned information used for the analysis of production in this study, also includes relevant information such as: name and address of the company, the existence of expansion plans, the number of employees, among others.

Regarding the sustainability of sea salt production, we chose the approach proposed by the Pressure-State-Response (PSR) method, elaborated by OECD (1983) to assess the area used for production, as well as the resources used during the production (e.g. abstraction of estuarine water). The model will be built considering the production circuit required for producing a ton of salt. Thus, we make a comparison between the area needed to produce a ton of sea salt and the volume of water needed for this production.

\section{RESULTS AND DISCUSSION}

\section{Production and management of Saltworks along the estuary}

The Salina Miramar, which is located at the estuary mouth and directly abstracts water from the sea, can maintain a stable pattern of production over the year, since the salinity of the ocean does not vary annually (35-40 ppm).

The Salina São Camilo, situated upstream (25 km away from the mouth), has its abstraction of water affected by the annual fluctuations of the water body, since between January and June, the estuary behaves, as a normal estuary, regarding salinity. In this condition, only the freshwater flow occurs in the stretch where the saltwork is situated, and this water is diluted in the ocean only in the river mouth.

However, based on actions of production engineering, even without effective abstraction, this saltwork maintains a pattern of continuous production through constant handling of the brine along the circuit of the saltwork, so that the salt production is not interrupted even with the absence of water abstraction. Through this technique of brine handling, the production values can be compared to those of the Salina Miramar.

In relation to production, whereas the Salina Miramar, among other saltworks located downstream, benefits a stable salinity in the local of water abstraction throughout the year. Thus, after the onset of the dry season (July to December) the water salinity along the water body increases gradually the salt saturation due to factors such as: 1) zero freshwater inflow from the river, 2) high temperatures and 3) constant winds. The combination of these factors favors the occurrence of high evaporation rates in the middle and upper estuary, where high values of salt saturation are observed in the water (50 to 90 ppm) (RAMOS e SILVA, 2004; SILVA et al., 2009).

Therefore, when compared to the production circuit of a saltwork, the upstream estuary operates as a natural evaporator. By capturing estuarine water with a high salt saturation, the saltworks located here (São Camilo, for instance), may anticipate their production circuit, not requiring the same time of production than the saltworks located downstream. Based on this description of the different production scenarios in the estuary of the River Apodi-Mossoró, comparisons are proposed between the areas required for production of the saltworks Miramar and São Camilo. 


\section{Evaluation on the use of natural resources}

From the analysis of the Table 1, we may observe that Salina Miramar utilizes a production area more than three times larger the used by Salina São Camilo, with a production only twice superior. In this relationship area/production is verified that by presenting a larger area, the Salina Miramar has a set of 5 water pumps (while São Camilo uses only one), resulting in a larger volume of demand for water resource.

Table 1 - Indicators evaluated for the calculation of the water used for sea salt production in the analyzed saltworks.

\begin{tabular}{|c|c|c|c|c|c|}
\hline Saltwork & Production area (ha) & $\begin{array}{c}\text { Total annual pro- } \\
\text { duction (ton.) }\end{array}$ & $\begin{array}{c}\text { Salinity of the local of } \\
\text { water abstraction }\end{array}$ & $\begin{array}{c}\mathbf{N}^{\mathbf{o}} \text { of } \\
\text { pumps }\end{array}$ & Pumping rate (m³/hour) \\
\hline Miramar & 1,668 & 360,000 & $35 \mathrm{ppm}$ & 05 & 3,000 \\
\hline São Camilo & 495 & 175,000 & $50-80 \mathrm{ppm}$ & 01 & 3,600 \\
\hline
\end{tabular}

Source - De Medeiros Rocha (2005).

Based on the values of annual production and required water volume, we found that in Salina Miramar, for each ton of salt produced, $60 \mathrm{~m} 3$ of water abstracted from the estuary are needed. On the other hand, the Salina São Camilo utilizes only $30 \mathrm{~m} 3$ of water. These values were obtained from the sum of pumping rate, quantity of pumps and pumping time over a year. To calculate the pumping time, we used an average value of 4 hours daily .

In relation to the area required for production, this value is easily obtained by dividing the value of the area used for production by the total annual production. In this way, the Table 2 shows that the production area per ton of sea salt produced by Salina Miramar is $50 \mathrm{~m} 2$. The Salina São Camilo presented an area of $30 \mathrm{~m} 2$ for the production of a ton of salt.

In addition to the data of needed area for production of a ton of salt, we also calculated the volume of water abstracted from the estuary for this production (Tab. 2). The analysis of this item represents the main natural resource consumed directly by a solar saltwork, and water is the only raw material involved throughout the production process. In this way, concerning the sustainability of sea salt production of the two companies examined, making the comparison between the volumes of water consumed annually by the saltworks, we register that the saltworks located upstream consumes only $18 \%$ of the total volume of water consumed by the downstream saltworks.

For the analysis of this factor, it should be stressed again that the saltworks located upstream are favored by the environmental conditions of the estuary, where water salinity in this sector is associated with the accumulation of tidal water, the high temperatures of the region $\left(>28^{\circ} \mathrm{C}\right)$ and constant winds. The synergism of these environmental forces promotes a high evaporation rate, creating a gradient of hypersalinity of water in the upstream stretch of the estuary. This hypersaline water favors the companies installed in this location, since the estuarine environment works as an initial evaporator during much of the year (7 to 8 months).

When defining the relationship between area and volume required for the production of salt in the estuary of the River Apodi-Mossoró, we highlight that the sea water is considered as a renewable resource (DAVIS, 2000). Mainly based on this assertion, the analysis of sustainability profile of sea salt production from solar evaporation is moving beyond a character merely oriented to the question of production space. Regarding this space issue, as shown in this study, the establishment of new saltworks in the downstream region leads to a consumption of water about five times greater than if the same would be located upstream. 
Table 2 - Calculation of the area required for the production of a ton of sea salt in the two analyzed saltworks (P.A. - Production Area; T.A.P. - Total Annual Production; V.C.E.W. - Volume Consumed of Estuarine Water; V.R.P.S. Volume (m3) Required for the Production of one salt Ton; A.R.P.T. - Area (ha) Required for the Production of one Ton of salt).

\begin{tabular}{|c|c|c|c|c|c|}
\hline Saltwork & P. A. (ha) & T. A. P. & V.C.E.W. $\left(\mathbf{m}^{3} /\right.$ year) & V.R.P.S. & A.R.P.T. \\
\hline Salina Miramar & 1,668 & 360,000 & $21,600,000$ & 60 & 05 \\
\hline São Camilo & 495 & 175,000 & $3,888,000$ & 30 & 03 \\
\hline
\end{tabular}

Source - De Medeiros Rocha (2005) / research data.

Following this reasoning, the required area for the salt production in the downstream region implies a drastic reduction of natural environment in the coastal zone, since a saltwork located here requires about $40 \%$ more area for production, in comparison to the upstream saltworks. However, it is noteworthy that the establishment of saltworks in the northern coast of Rio Grande do Norte State occurred with the use of saline lowlands of the rivers in the region (DE MEDEIROS ROCHA, 2005). In this littoral of semiarid climate, after the rainy season (January-July), high tides along the mouths of the rivers are followed by deposition and accumulation of salts over riparian areas, resulting in the occurrence of salt crusts.

\section{CONCLUSION}

The analysis of the 'area and volume' relationship required for the production of sea salt through evaporation shows that the sustainability is found in the possibility of the nature provide sufficient resource to meet present and future demands and to maintain the economy indefinitely. The applied method is a tool of communication and comparison of environmental impacts resulting from different projects.

In summary, the method shows in numerical values, how much the support capacity of the environment was appropriate for salting activity, as it expresses the appropriation of resources as a function of their use per capita. This tool provides an aggregate result of the appropriate area of land and volume of water that reflects the ecological impact of different types of human activities. Our results lead to the conclusion that the area size required by the salting activity depends on its geographical position along the estuary.

Therefore, we verified that even being located in a semiarid climate region, both studied saltworks presented distinct environmental situations along the margins of the water body. The application of this criterion may also explain some nuances of salt production in Brazilian northeastern coast.

\section{ACKNOWLEDGEMENTS}

The authors wish to thank the LAMA - UFRN/CERES (Laboratory of Environmental Monitoring) for the support during field and office work, as well the managers of the saltworks (NORSAL - Norte Salineira S.A. and Salineira São Camilo LTDA) who allowed access and provided all the resources at our disposal to accomplish this research. Diógenes F. S. Costa is grateful to CAPES for research fellowship granted (Proc. BEX. 5834/10-4) and CNPq for financial support (Universal Proc.447227/2014-9). We also thank the anonymous referee for the careful reading and the valuable comments and constructive suggestions, which substantially improved the quality of the paper. 


\section{REFERENCES}

COSTA, D. F. S. Análise fitoecológica do manguezal e ocupação das margens do estuário hipersalino Apodi-Mossoró (RN - Brasil). Master Thesis (Mestrado em Desenvolvimento e Meio Ambiente) - Universidade Federal do Rio Grande do Norte, Natal, Brasil, 2010, 79 p.

DAVIS, J. S. Structure, function, and management of the biological system for seasonal solar saltworks. Global Nest Journal, v. 2, n. 3, p. 217-226, 2000.

DAVIS, J. S. Management of biological systems for continuously operated solar saltworks. Global Nest Journal, v.11, n. 1, p. 73-78, 2009.

DE MEDEIROS ROCHA, R.; CÂMARA, M. R. Prediction, monitoring and management of detrimental algal blooms on solar saltworks. In: 7rd International Symposium on Salt, anais... Salt Institute, v. 1, p. 657-660, 1993.

DE MEDEIROS ROCHA, R. Cadastro das atividades salineiras e de carcinicultura no estuário do Rio Apodi-Mossoró (RN). Instituto de Defesa do Meio Ambiente do Rio Grande do Norte / Fundação para o Desenvolvimento Sustentável das Terras Potiguares, Natal/RN, Brasil, 2005, 50 p. (unpublished).

DE MEDEIROS ROCHA, R.; COSTA, D. F. S.; LUCENA FILHO, M. A. Tropical solar salt works - influence and challenges in the coexistence with traditional populations in the Brazilian northeast region. In: 9th International Symposium on Salt, anais... Beijing, China, v. 1, p. 877-881, 2009.

KOROVESSIS, N. A.; LEKKAS T. D. Solar saltwork's wetland function. Global NEST Journal, v. 11, n. 1, p. 49-57, 2009.

LÓPEZ, E.; AGUILERA, P. A.; SCHMITZ, M. F.; CASTRO, H.; PINEDA, F. D. Selection of ecological indicators for the conservation, management and monitoring of Mediterranean coastal salinas. Environmental Monitoring and Assessment, v. 166, n. 3, p. 241-256, 2010. DOI 10.1007/s10661-009-0998-2.

MOOSVI, S. J. Ecological importance of solar saltworks. In: Proceedings of the 1st International Conference on the Ecological Importance of Solar Saltworks, anais... (CEISSA 06), October 20-22, Santorini Island, Greece, 2006.

OECD. ORGANIZATION FOR ECONOMIC COOPERATION AND DEVELOPMENT. Organization for economic cooperation and development: core set of indicators for environmental performance reviews; a synthesis report by the group on the state of the environment. Paris: OCDE, 1993.

OREN, A. Saltern evaporation ponds as model systems for the study of primary production processes under hypersaline conditions. Aquatic Microbiology and Ecology, v. 56, p. 193-204, 2009.

PEDRÓS-ALIÓ, C.; CALDERÓN-PAZ, J. I.; MACLEAN, M. H.; MEDINA, G.; MARRASÉ, C.; GASOL, J. M.; GUIXA-BOIXEREU, N. The microbial food web along salinity gradients. FEMS Microbiology and Ecology, v. 32, p. 143-155, 2000.

RAMOS e SILVA, C. A. Caracterização física, físico-química e química dos estuários Apodi, Conchas, Cavalos, Açu, Guamaré, Galinhos, Ceará-Mirim, Potengi, Papeba e Guaraíra. Relatório final. Instituto de Desenvolvimento Econômico e Meio Ambiente do Rio Grande do Norte/IDEMA, Natal/RN, Brasil, 2004, 36p. (unpublished).

ROCHA, A. P. B. Expansão urbana de Mossoró/RN (período de 1980 a 2004): geografia, dinâmica e reestruturação do território. Master Thesis. Programa de Pós-graduação em Geografia. Universidade Federal do Rio Grande do Norte, Natal/RN, 2005.

SILVA, A. M. A.; BARBOSA, J. E. L.; MEDEIROS, P. R.; De MEDEIROS ROCHA, R.; LUCENA FILHO, M. A.; COSTA, D. F. S. Zooplankton (Cladocera and Rotifera) variations along a horizontal salinity gradient and during two seasons (dry and rainy) in a tropical inverse estuary (Northeast Brazil). Pan-American Journal of Aquatic Sciences, v. 4, n. 2, p. 226-238, 2009.

SOUTO, F. J. B., De Medeiros Rocha, R. M., Barbosa, J. E. L., Watanabe, T. Distribuição espaço-temporal da comunidade fitoplanctônica e variáveis hidrológicas em uma salina artesanal do estado do Rio Grande do Norte, Brasil. Revista Nordestina de Biologia, v. 15, n. 2, p. 7-26, 2000 a. 
SOUTO, F. J. B., De Medeiros Rocha, R. M., Watanabe, T. Influência de parâmetros ambientais sobre Artemia sp. (Branchiopoda: Artemiidae) em uma salina artesanal do Estado do Rio Grande do Norte. Revista Nordestina de Biologia, v. 14, n. 1/2, p. 1-16, 2000 b.

VIEIRA, N.; BIO, A. Spatial and temporal variability of water quality and zooplankton in an artisanal salina. Journal of Sea Research, v. 65, p. 293-303, 2011.

Trabalho enviado em março de 2015 Trabalho aceito em abril de 2015 